\title{
PURIFICATION OF PREGNANT SOLUTION RESULTED FROM SPHALERITE CONCENTRATE EXTRACTION USING SULFATE ACID FOR ZINC OXYDE PRODUCTION
}

\author{
PEMURNIAN LARUTAN KAYA HASIL EKSTRAKSI KONSENTRAT \\ SFALERIT DENGAN ASAM SULFAT UNTUK PEMBUATAN SENG \\ OKSIDA
}

\author{
YUHELDA $^{1}$, DESSY AMALIA ${ }^{2}$, PUTRI D. NOVIANTI ${ }^{3}$ and ERLINA YUSTANTI ${ }^{3}$ \\ ${ }^{1}$ Geological Survey Centre \\ Jalan Diponegoro 57 Bandung \\ e-mail: yuhelda.dahlan@gmail.com \\ ${ }^{2}$ Research and Development Centre for Mineral and Coal Technology \\ Jalan Jenderal Sudirman 623 Bandung 40211 \\ ${ }^{3}$ University of Sultan Agung Tirtayasa \\ Jalan Jenderal Sudirman Km 3 Cilegon, Banten 42435, Indonesia
}

\begin{abstract}
Purification of pregnant solution from sphalerite concentrate extraction using sulfate acid to produce zinc oxide was meant to prepare zinc oxide production technology utilizing existing internal sphalerite mineral raw material. The pregnant solution used to produce zinc oxide contains $29.84 \%$ zinc $(\mathrm{Zn})$, with the biggest impurities iron (Fe) $11.68 \%$. In order to obtain high purity zinc oxide, the pregnant solution should be recovered. It was done through a solvent extraction method, in two process steps: extraction and stripping. The extraction was applying ligan bis di2ethylhexyle phosphate acid (D2EHPA) in toluene solvent, through ligan concentrate variation, $\mathrm{pH}$ and comparison of aqueous volume with organic volume $\left(\mathrm{V}_{\mathrm{A}}: \mathrm{Vo}\right)$ and its excess. Stripping was carried out using sulfate acid through variation of concentration, $\mathrm{pH}$ and $\mathrm{Vo}: \mathrm{V}_{\mathrm{A}}$. To obtain optimum recovery, thus extraction and stripping should be carried out in many steps. The extractions and the strippings were calculated using McCabe Thiele diagram. Furthermore, zinc oxide was resulted from deposition and calcination of pure pregnant solution at temperature $500^{\circ} \mathrm{C}$. Purification results show that the best extraction occurred at concentration D2EHPA $1 \mathrm{M}, \mathrm{pH} 3$ and $\mathrm{Vo}: \mathrm{Va} 2: 1$, through 4 step processes obtained recovery $97.50 \%$ with distribution coefficient 77.9; while the best stripping was obtained at $\mathrm{H}_{2} \mathrm{SO}_{4}$ concentration $2 \mathrm{M}$, $\mathrm{V}_{\mathrm{O}}: \mathrm{V}_{\mathrm{A}} 2: 1$ through 3 step processes which obtained stripping percent $98.22 \%$ with stripping coefficient 1.51. On the other hand, zinc oxide solution resulted from purification was obtained $\mathrm{Zn} 93.31 \%$ in the form of hexagonal crystals (wurtzite).
\end{abstract}

Keywords: pregnant solution zinc sulphate, zinc oxide, purification, solvent extraction, tripping, precipitation and calcination

\begin{abstract}
ABSTRAK
Pemurnian larutan kaya hasil ekstraksi kosentrat sfalerit dengan asam sulfat untuk pembuatan seng oksida ( $\mathrm{ZnO}$ ) bertujuan untuk menyiapkan teknologi pembuatan seng oksida dengan memanfaatkan bahan baku mineral sfalerit di dalam negeri. Larutan kaya yang digunakan sebagai bahan baku pembuatan seng oksida mengandung seng $(Z n)$ sebesar $29,84 \%$, dengan pengotor terbesar adalah besi (Fe) 11,68\%. Untuk mendapatkan seng oksida dengan kemurnian yang tinggi, maka bahan baku (larutan kaya) perlu dimurnikan (recovery). Pemurnian larutan kaya dilakukan dengan metode solvent extraction (ekstraksi pelarut), dengan dua tahap proses, yaitu: ekstraksi dan stripping. Ekstraksi dilakukan menggunakan ligan bis (di2ethylhexylephosphate) acid (D2EHPA) di dalam pelarut toluen, dengan memvariasikan kosentrasi ligan, $\mathrm{pH}$, perbandingan volume aqueous dengan volume organik (Va:Vo) dan exsess volume organik. Sementara itu, stripping dilakukan menggunakan asam sulfat
\end{abstract}


dengan memvariasikan kosentrasi dan perbandingan larutan organik dengan volume larutan aqueous $\left(V_{0}: V_{A}\right)$. Untuk mendapatkan recovery (kemurnian) yang optimal, maka proses ektstraksi dan stripping dilakukan pada beberapa tahapan proses. Banyak tahapan proses yang dilakukan dihitung menggunakan diagram McCabe Thiele. Selanjutnya, pembuatan seng oksida dari larutan kaya murni dilakukan melalui proses pengendapan dan kalsinasi pada suhu $500^{\circ} \mathrm{C}$. Hasil pemurnian menunjukkan ekstraksi terbaik terjadi pada kosentrasi D2EHPA $1 \mathrm{M}, \mathrm{pH} 3$, perbandingan Vo : Va 2:1, 2\% excess volume organik dengan 4 tahap proses menghasilkan persen ekstraksi sebesar 97,50\% dengan koefisien distribusi 77,9, sedangkan stripping terbaik diperoleh pada konsentrasi $\mathrm{H}_{2} \mathrm{SO}_{4} 2 \mathrm{M}$, perbandingan $V_{O}: V_{A} 1: 2$ pada 3 tahapan dengan persen stripping sebesar 98,22\% dengan koefisien stripping 1,51. Sedangkan dari pembuatan seng oksida dari larutan kaya hasil pemurnian diperoleh seng oksida dengan kandungan seng seng (Zn) sebesar 93,31\% dalam bentuk kristal heksagonal (wurtzite).

Kata kunci: larutan kaya seng sulfat, seng oksida, pemurnian, ekstraksi pelarut, tripping, kristalisasi dan kalsinasi

\section{INTRODUCTION}

Zinc oxide is an inorganic compound with chemical formula $\mathrm{ZnO}$, of white powder form with minimal $\mathrm{ZnO}$ content $93 \%$ (Habashi, 1997), unsolved in the water and diamagnetic character. This compound could be used as additive, glass, ceramic, plastic, cement, glue, pigment, food, and semiconductor. As a semiconductor it has bandgap energy $3.37 \mathrm{eV}$. The wide bandgap $(3.2-3.8 \mathrm{eV})$ could release fast electron under sun heat, thus it could be used for thin-film solar cell (Gonzalez-Valls and LiraCantu, 2009).

A lot of zinc oxide utilization is supported by the national energy government policy. The internal zinc oxide needs, based on the Ministry of Industry import data in 2016, are US $\$ 14,949,300$. The high import encourages Indonesia to produce zinc oxide using abundant sphalerite minerals in this country with total resources 19.8 million tons (Directorate General of Mineral and Coal, 2015).

Zinc oxide production from sphalerite had been started in 2004 through a roasting process. This process changes the $\mathrm{ZnS}$ into $\mathrm{ZnO}$ with small recovery of $87 \%$. This process also produced zinc oxide, which still contains $7 \%$ of $\mathrm{Fe}_{2} \mathrm{O}_{3}$, and approximately $1 \%$ of $\mathrm{CuO}$ and $\mathrm{PbO}$ (Nyberg, 2004; Waddar and Behera, 2010). The existence of $\mathrm{Fe}_{2} \mathrm{O}_{3}$ in the $\mathrm{ZnO}$ product results in a brownish-yellow powder (Nyberg, 2004); thus, it is necessary to separate the $\mathrm{Fe}_{2} \mathrm{O}_{3}$ to obtain a white color $\mathrm{ZnO}$ powder which has a content of $\geq 93 \%$.

Separation the $\mathrm{Fe}_{2} \mathrm{O}_{3}$ in $\mathrm{ZnO}$ mixture is very difficult, considering that iron oxide is paramagnetic (weak magnetic character), that could not be separated by magnetization method as well as by density, as $\mathrm{Fe}_{2} \mathrm{O}_{3}(5.24$ $\mathrm{g} / \mathrm{cm}^{3}$ ) density almost equal with $\mathrm{ZnO}$ (5.61 $\mathrm{g} / \mathrm{cm}^{3}$ ) density. On the other hand, the roasting process will dispose of the $\mathrm{SO}_{2}$ gas that is very dangerous to the environment and could cause acid rain. This process produces low content $\mathrm{ZnO}$ less than $93 \%$, which should have contained more than $93 \%$ (Habashi, 1997). All these conditions mentioned require effective and economical methods for making the $\mathrm{ZnO}$ from sphalerite.

The effective and economic method was obtained through the hydrometallurgical process, because the process has high selectivity to metals (Moezzi, McDonagh and Cortie, 2012). Some research studies have been conducted such as by Gupta (2003) with $\mathrm{ZnO}$ result $90.4 \%$ without recovery treatment from the resulted solution. Recovery was meant to dispose of the impurities, thus it could increase the $\mathrm{ZnO}$ content in the pregnant solution. The recovery process could be carried out through solvent extraction, using an organic solution to separate $\mathrm{Zn}^{2+}$ from other metal iron impurities (Kislik, 2011; Moezzi, McDonagh and Cortie, 2012). The process could be executed through two steps, namely extraction and stripping (Gupta, 2003).

$\mathrm{Zn}^{2+}$ extraction from a pregnant solution was carried out through solvent extraction using a ligand or extractant in an organic solvent. The already used ligands are bis (2Ethylhexyl) phosphate acid (D2EHPA) and bis (2.4.4-trimethylpentyl) phosphinic acid (CYANEX 272) (Balesini et al., 2011). Usage of D2EHPA ligand results in 39\% extraction in a one-step process, while using CYANEX 
272 provides $41 \%$ extraction also from a one-step process (Nathsarma and Sarma, 2003; Asadi, Azizi, Lee and Jahani, 2018). From both ligands used, D2EHPA is more economical due to its lower price performing 1.1 million rupiahs for $100 \mathrm{ml}$ volume compared to CYANEX 272 ligand that reaches 2.7 million rupiahs with the same volume (Sigma-Aldrich, 2018), thus D2EHPA ligand is being more used for recovery the zinc sulfate enriched solution. In the stripping process that has been carried out to look for the best solvent, has been conducted by Singh and Dhadke (2002) using nitrate $\left(\mathrm{HNO}_{3}\right)$ and sulfate $\left(\mathrm{H}_{2} \mathrm{SO}_{4}\right)$ acids. Using the $\mathrm{HNO}_{3}$, it was obtained a $40 \%$ stripping percentage while by $\mathrm{H}_{2} \mathrm{SO}_{4}$, it was obtained $43 \%$ for a onestep process, thus researchers prefer to use sulfate acid for stripping.

$\mathrm{Zn}^{2+}$ from zinc sulfate pregnant solution, the process could be accomplished many times and the calculation applies McCabe Thiele diagram. The repeated recovery would be economic because the ligand and solvent used could be re-purified.

$\mathrm{ZnO}$ making from pure zinc sulfate pregnant solution could be carried out through precipitation and calcination processes at a temperature of $500^{\circ} \mathrm{C}$, to gain a white powder of $\mathrm{ZnO}$ with the minimum content of 93\% hexagonal of wurtzite (KołodziejczakRadzimska and Jesionowski, 2014; Sadraei, 2016).

\section{METHOD}

\section{Material and Equipment}

\section{Material}

The used materials are zinc sulfate pregnant solution resulted from sphalerite concentrate of PT Lumbung Mineral Sentosa, in Bogor, West Java, with a zinc content of $29.84 \%$. While the consumables are add aqua distillate, $d=125 \mathrm{~mm}$ (Whatman) sieving paper, solution of $\mathrm{ZnSO}_{4} 0.1 \mathrm{~mol} / \mathrm{L}$ (Merck), $\mathrm{pH}$ indicator universal (Merck), toluene pro analyst (Merck), D2EHPA (bis (2-Ethylhexyl) phosphate) acid 97\% (Sigma-Aldrich), $\mathrm{H}_{2} \mathrm{SO}_{4}$ (sulfuric acid) pro analyst 95-97\% (Merck) and $\mathrm{NH}_{4} \mathrm{OH}$ (ammonium hydroxide) $32 \%$ (Merck).

\section{Equipment}

Equipment used consists of hot plate magnetic stirrer (c-mag hs-10), separate funnel, crucible, muffle furnace (Thermolyne) and chemical glasses, porcelain mortar, digital weighting. The analytical tool used AAS (Varian, 240 FS) to identify metal contents in the raw material and in the solution of extraction result and $\mathrm{ZnO} X \mathrm{RD}$ product (Shimadzu, Lab Center XRF-1800) to identify $\mathrm{Zn}$ content and its impurities from the obtained $\mathrm{ZnO}$.

\section{Experimental Procedure}

Production of zinc oxide from zinc sulfate pregnant solution resulted from leaching of one-kilo sphalerite mineral concentrate for the whole experiment was conducted in two stages, firstly pregnant solution and secondly zinc oxide; with the flow diagram shown in Figure 1.

\section{Recovery}

Recovery was meant to separate zinc metal ions $\left(\mathrm{Zn}^{2+}\right)$ from other metal ions that exist in the raw material (zinc sulfate pregnant solution) using the method of solvent extraction. The recovery was achieved through two process stages, i.e. extraction and stripping. Extraction was using D2EHPA ligand in the toluene solvent. Determination of parameters in the extraction stage was used pure $\mathrm{ZnSO}_{4}$ solution. Extraction steps were accomplished through ligand concentration variation of D2EHPA, namely $0.4,0.6,0.8,1.0$ and $1.2 \mathrm{M}$ at $\mathrm{pH}$ condition 3 and $V_{A}: V_{O}$ is $1: 1$. The best concentration was used to be varied with $\mathrm{pH} \mathrm{1,} \mathrm{2,} \mathrm{3,} 4$ and 5 with $\mathrm{V}_{\mathrm{A}}: \mathrm{V}_{\mathrm{O}}$ condition $1: 1$. After that, it was carried out $\mathrm{V}_{\mathrm{A}}: \mathrm{V}_{O} 5: 1,2: 1,1: 1,2,1: 5$ at the best concentration D2EHPA ligand and the best $\mathrm{pH}$ obtained from the previous process.

Results of variation $\mathrm{V}_{\mathrm{A}}: \mathrm{V}_{\mathrm{O}}$ was performed in McCabe Thiele to obtain theoretical stages that should be carried out in order to get maximum extraction. The obtained operation parameters were then applied to the zinc sulfate pregnant solution (the raw material) with \% excess organic solution volume 0, 2, 4 and $6 \%$. The organic solution obtained at the extraction stage was then separated using aqueous solution. Furthermore, the aqueous solution was analyzed using an AAS. 


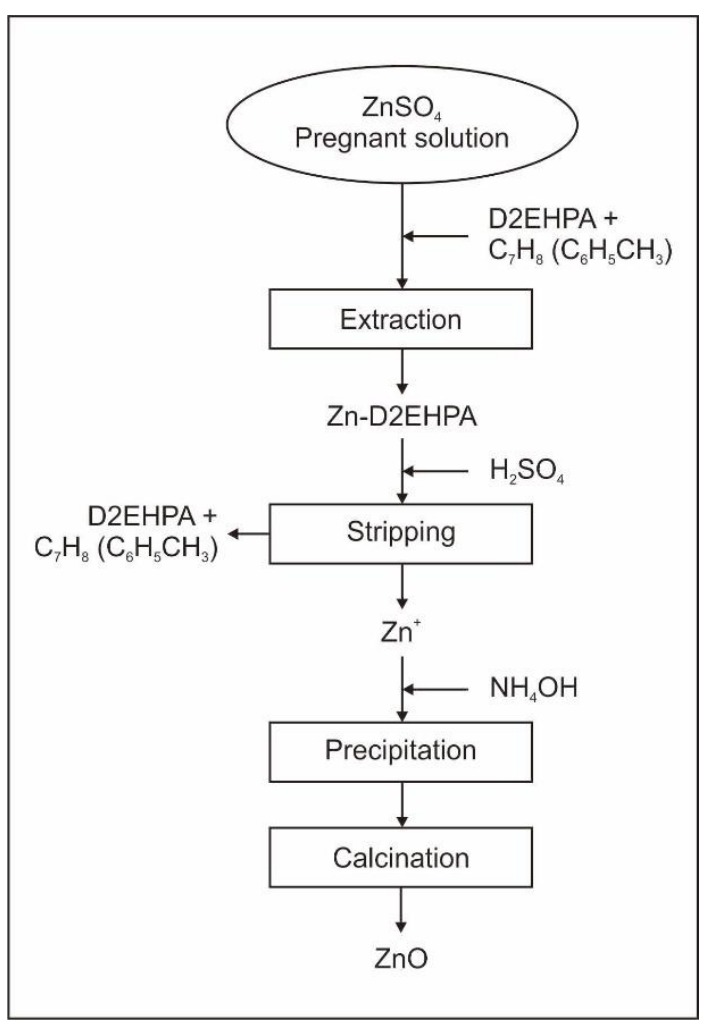

Figure 1. Process flow diagram of $\mathrm{ZnO}$ from zinc sulfate pregnant solution

The zinc ion attached to the ligand in the toluene solvent should be returned to the ion in aqueous solution using $\mathrm{H}_{2} \mathrm{SO}_{4}$ acid, in order to get easier to be processed to become $\mathrm{ZnO}$. The returning process was recognized as stripping.

Stripping was carried out with a variation of sulfuric acid concentration from $0.1,0.4,0.7$, 1.0 to $1.3 \mathrm{M}$ (Wen-qing, Zhuo-yue, Weizhong and Guan-zhou, 2003) at $V_{0}: V_{A}$ is 1:1. The best concentration was obtained at volume variation $V_{0}: V_{A}$ of $5: 1,2: 1,1: 1,1: 2$ and 1:5 (Nathsarma and Sarma, 2003). Results of $V_{0}: V_{A}$ variation was performed in McCabe Thiele to obtain theoretical stages that should be carried out in order to have a maximum executed extraction. The resulted operational parameters were then applied for an organic solution from the extraction process. The resulted aqueous solution, separated using an organic solution, was then analyzed using AAS.

Raw materials used are a pregnant solution from extraction concentrate of sphalerite mineral of PT Lumbung Mineral Sentosa using sulfuric acid $\left(\mathrm{H}_{2} \mathrm{SO}_{4}\right)$, with chemical composition as shown in Table 1.

Table 1. Chemical composition pregnant solution of zinc sulfate (raw material)

\begin{tabular}{cc}
\hline Element & Composition (\%) \\
\hline $\mathrm{Zn}$ & 29.84 \\
$\mathrm{Cu}$ & 0.01 \\
$\mathrm{~Pb}$ & 0.02 \\
$\mathrm{Fe}$ & 11.68 \\
\hline
\end{tabular}

\section{Zinc Oxide Production}

Zinc oxide production from pregnant solution obtained from recovery was carried out through precipitation and calcination processes. As much as $200 \mathrm{ml}$ pregnant solution was added with $\mathrm{NH}_{4} \mathrm{OH}$ until $\mathrm{pH} 9$ and white deposit occurred. The deposit obtained was then separated, washed, dried, and calcined at $500^{\circ} \mathrm{C}$ (Morkoç and Özgür, 2009; Arief, 2011; Kołodziejczak-Radzimska and Jesionowski, 2014). The obtained zinc oxide was then weighted, analyzed with an XRF instrument and determined its crystal structures.

\section{RESULTS AND DISCUSSION}

\section{Raw material}

Table 1 shows that the raw material contains $\mathrm{Zn} 29.84 \%$ with iron impurities of $11.68 \%$; while $\mathrm{Cu}$ and $\mathrm{Pb}$ impurities are small, namely around $0.02 \%$. The rest are other metal ions. The existence of $\mathrm{Cu}, \mathrm{Pb}$ and $\mathrm{Fe}$ due to the leached concentrate sphalerite - $(\mathrm{Zn}, \mathrm{Fe}) \mathrm{S}$ still contains chalcopyrite $\left(\mathrm{CuFeS}_{2}\right)$, pyrite $\left(\mathrm{FeS}_{2}\right)$, galena $(\mathrm{PbS})$ and other secondary minerals. The high iron content in the raw material causes a brownish-yellow $\mathrm{ZnO}$ instead of white. Besides the high content of $\mathrm{Fe}_{2} \mathrm{O}_{3}$, the amount of $\mathrm{Zn}$ is still low for $\mathrm{ZnO}$, thus a recovery process is needed. The recovery should increase $\mathrm{ZnO}$ content until $\geq 93 \%$. Recovery using the solvent extraction method could increase $\mathrm{Zn}$ content in the pregnant solution until 98\% (Kislik, 2011; Moezzi, McDonagh and Cortie, 2012).

\section{Recovery}

\section{Extraction}

Recovery using solvent extraction was done in two steps, i.e. extraction and stripping (Gupta, 2003). Extraction using ligand 
(D2EHPA) in toluene solvent with concentration variation D2EHPA of $0.4,0.6$, $0.8,1.0$ and $1.2 \mathrm{M}$ at the condition of $\mathrm{pH} 3$ and $V_{A}: V_{O}$ of $1: 1$, the results are shown in Figure 2, with the chemical reaction as follows:

$\mathrm{ZnSO}_{4(\mathrm{aq})}+\left[(\mathrm{RO})_{2} \mathrm{PO}_{2} \mathrm{H}_{2(\text { org })} \rightleftharpoons \mathrm{H}_{2} \mathrm{SO}_{4(\mathrm{aq})}+\right.$ $\left[(\mathrm{RO})_{2} \mathrm{PO}_{2}\right]_{2} \mathrm{Zn}_{\text {(org) }}$

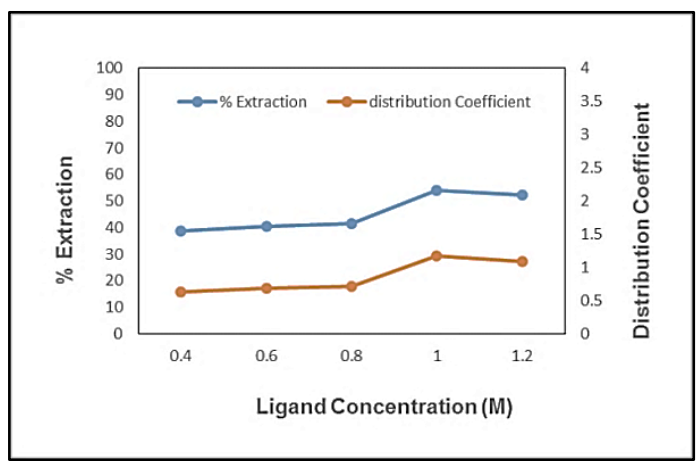

Figure 2. Influence of D2EHPA concentratin to percentage extraction and distribution coefficient.

Figure 2 shows maximal results obtained at concentration $1 \mathrm{M}$ with extraction percentage $53.95 \%$ and distribution coefficient 1.17 . Where the distribution coefficient could calculate by formula as follows:

$$
\begin{aligned}
& D=\frac{C o}{C A} \\
& D=\text { Distribution coefficient } \\
& C o=\text { Concentration into organic } \\
& C_{A}=\text { Concentration into aqueous }
\end{aligned}
$$

At higher D2EHPA concentration, more ion $\mathrm{Zn}^{2+}$ moves to the organic phase, thus it will obtain extraction percentage higher (Kislik, 2011). The distribution coefficient at $0.4 \mathrm{M}$ concentration increases from 0.63 to 1.17 . This is due to many $\mathrm{Zn}^{2+}$ ions move from the aqueous phase to the organic phase (Kislik, 2011). At concentration $1.2 \mathrm{M}$, there is a decrease in percentage extraction to $52.23 \%$ with a distribution coefficient of 1.09. Such a decrease occurs due to the formation of a dimer in the organic phase that causes the extracted metal amount is less compared to the theoretical one. Dimer formation occurs due to hydrogen bond at a high concentration where the ligand collides with each other, thus preventing the $\mathrm{Zn}^{2+}$ to attach, besides it attaches other D2EHPA (Kertes, 1971).
Hydrogen ion would be released by D2EHPA ligand into aqueous solution thus decreases $\mathrm{pH}$ solution. If the $\mathrm{pH}$ is not regulated, the $\mathrm{pH}$ decrease will cause left direction reaction, namely releasing the ion $\mathrm{Zn}^{2+}$ from the organic phase into the aqueous phase (Kertes, 1971). The results are shown in Figure 3.

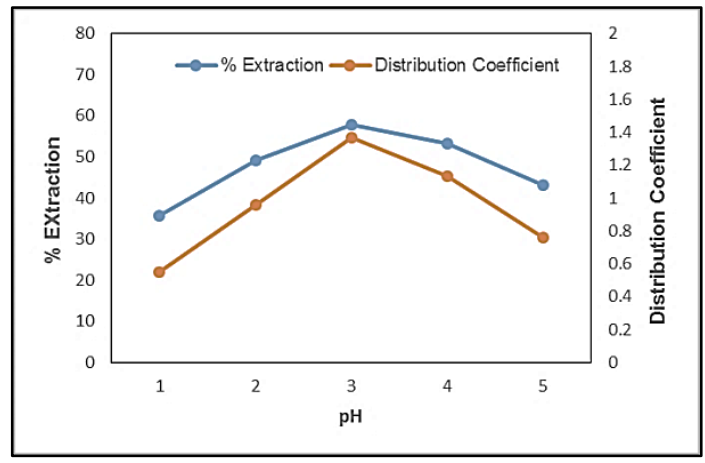

Figure 3. Influence of $\mathrm{pH}$ to percentage extraction and distribution coefficient

Figure 3 shows the maximal result at $\mathrm{pH} 3$ with an extraction percentage of $57.86 \%$ and a distribution coefficient of 1.37 that is bigger than the distribution coefficient at another $\mathrm{pH}$. This is in accordance with the research results by Rajeev K. Singh and P.M Dhadke in 2002 where $\mathrm{Zn}$ extraction using organic solution D2EHPA in toluene occurred at $\mathrm{pH}$ range of $2.5-3.0$ (Singh and Dhadke, 2002).

Figure 3 also shows that the increase of $\mathrm{pH}$ causes the increase of extraction percentage until at a certain $\mathrm{pH}$ value, then it decreases with the increase o pH. If $\mathrm{pH}$ is low, the $\mathrm{Zn}^{2+}$ ion in the organic phase will decrease due to ligand protonation that the ligand is becoming difficult to attached to ion $\mathrm{Zn}^{2+}$. If $\mathrm{pH}$ is high, ion $\mathrm{Zn}^{2+}$ would be hydrolyzed and it could not be brought into the organic phase. The best extraction process takes place at $\mathrm{pH}$ value exactly before ion $\mathrm{Zn}^{2+}$ hydrolyzed (Kertes, 1971).

Variation ratio of aqueous volume; organic volume $\left(\mathrm{V}_{\mathrm{A}}: \mathrm{V}_{\mathrm{O}}\right)$ with ligand concentration D2EHPA $1 \mathrm{M}$ and pH 3 is shown in Figure 4.

Figure 4 shows that the maximal results were obtained at ratio aqueous volume to organic volume of 2:1 with the extraction percentage of $54.63 \%$ and distribution 
coefficient value of 2.41 . The selection of maximal results at this variation was based on a higher value of distribution coefficient compared to other $\mathrm{V}_{\mathrm{A}}: \mathrm{V}_{\mathrm{O}}$. The high value of the distribution coefficient shows that the concentration of $\mathrm{Zn}^{2+}$ ion in the organic phase is higher than that in aqueous solution (Kislik, 2011).

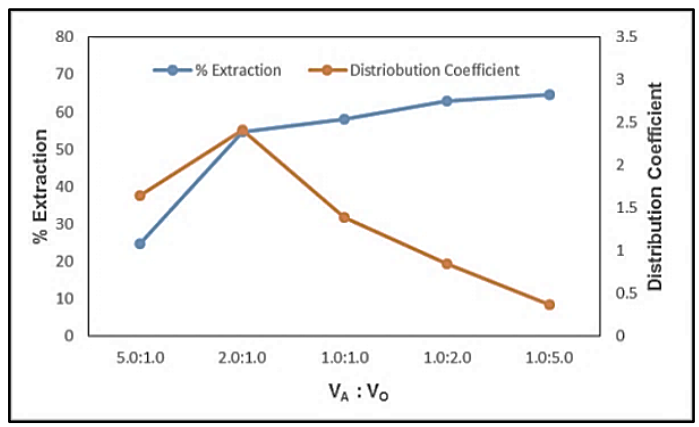

Figure 4. Influence $\mathrm{V}_{\mathrm{A}}: \mathrm{V}_{\mathrm{O}}$ to percentage extraction and distribution coefficient

The increased amount of organic solution will enhance the extraction percentage up to $64.63 \%$ at ratio $\mathrm{V}_{\mathrm{A}}: \mathrm{V}_{\mathrm{O}}$ of $1: 5$. The result is in accordance with the research conducted by Balesini et al. that the increased of organic phase volume would be more attached $\mathrm{Zn}^{2+}$ ion, thus the extraction percentage would be higher (Balesini, Razavizadeh and Zakeri, 2011). The increased in organic solution volume causes the equilibrium to move to the right direction of the product formation.

Distribution coefficient value of $\mathrm{V}_{\mathrm{A}}: \mathrm{V}_{\mathrm{O}}$ at $2: 1$ decreases from 2.41 to 0.37 at 1:5. The distribution of $\mathrm{Zn}^{2+}$ into the organic phase solution is decreasing with the high volume of organic phase solution because the highest organic phase volume is incomparable with the $\mathrm{Zn}^{2+}$ content in the aqueous phase. At the same $\mathrm{Zn}^{2+}$ concentration in higher organic phase volume, the attached $\mathrm{Zn}^{2+}$ at the organic phase will be less thus distribution coefficient value decrease (Kislik, 2011).

McCabe Thiele diagram was made based on ratio $\mathrm{V}_{\mathrm{A}}: \mathrm{V}_{\mathrm{O}}$ is shown in Figure 5.

Figure 5 demonstrates that a high concentration of dissolved zinc in aqueous solution will increase the dissolved zinc concentration and move to the aqueous phase. Based on diagram McCabe Thiele, stages required to obtain maximal extraction percentage at ratio $V_{A}: V_{O}$ of $2: 1$ is 4 stages.

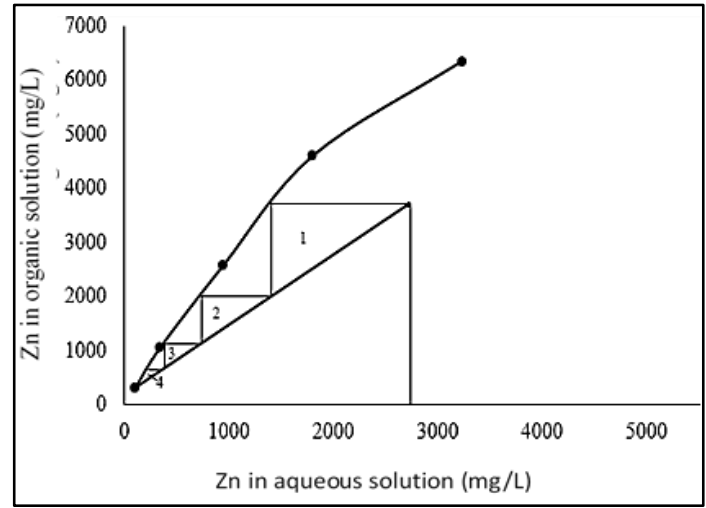

Figure 5. McCabe Thiele diagram extraction stage

The obtained operational parameters were then applied at the pregnant solution (raw material) with a variation of percent excess volume organic solution (D2EHPA ligand), with extraction results as shown in Figure 6.

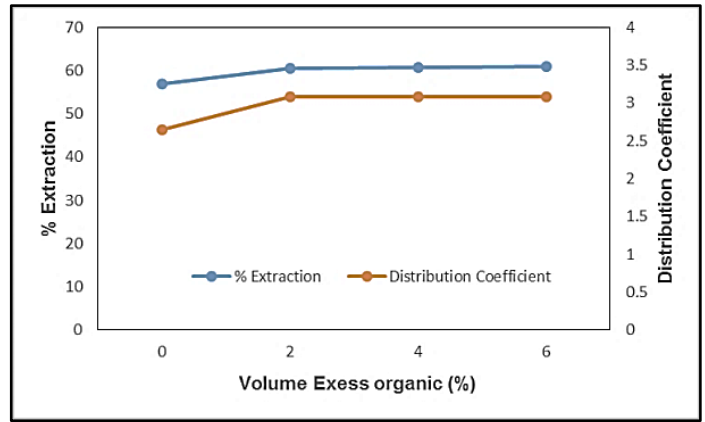

Figure 6. Influence \%excess volume D2EHPA to percentage extraction and distribution coefficient

Figure 6 shows the result of the percent excess maximum volume at $2 \%$ with an extraction percentage of $60.62 \%$. This is supported by a high distribution coefficient at 3.08 volume excess. The increased volume excess percentage of D2EHPA applied to the samples will increase the obtained extraction percentage. This is due to the abundances of $\mathrm{Zn}^{2+}$-containing organic solution disturbs reaction of equilibrium to the right direction or to the product.

Based on McCabe Thiele diagram, theoretical extraction is needed to obtain 
maximum extraction percentage and should be carried out in 4 stages. These stages were executed through the re-extracted aqueous solution that still contains $\mathrm{Zn}^{2+}$ from the first stage. Figure 7 shows the stages of extraction and its coefficient distribution.

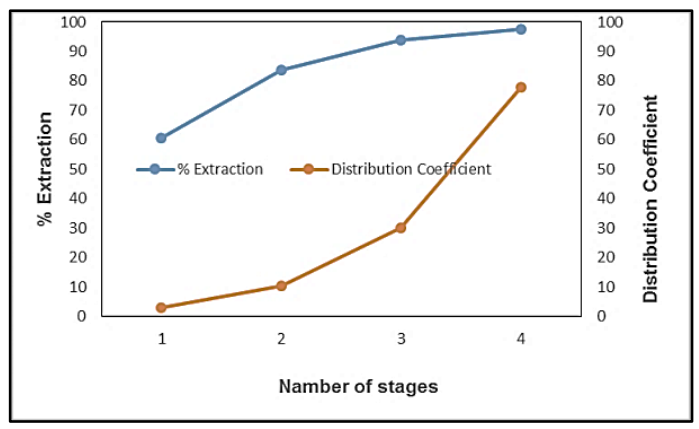

Figure 7. Extraction stages yields to percentage extraction and coefficient distribution

Figure 7 reveals the zinc percent extraction that was done in 4 stages and resulted in $97.50 \%$ with a distribution coefficient of 77.9 . The percentage extraction will increase in each stage comply with the concentration obtained in its organic phase solution. The extraction percentage that did not reach $99.9 \%$ due to the existence of other metal ions brought into the organic phase. The increased distribution coefficient in each stage helps to explain that $\mathrm{Zn}^{2+}$ concentration at the aqueous phase has been distributed into the organic phase.

\section{Stripping}

Stripping was conducted using $\mathrm{H}_{2} \mathrm{SO}_{4}$ to take back $\mathrm{Zn}^{2+}$ existed in the organic phase to the aqueous phase, through variation of $\mathrm{H}_{2} \mathrm{SO}_{4}$ concentration and ratio $\mathrm{Vo}: \mathrm{VA}$ as shown in Figures 8 and 9.

Figure 8 demonstrates that the higher the $\mathrm{H}_{2} \mathrm{SO}_{4}$ concentration the bigger the percentage stripping. The biggest stripping of $72.41 \%$ was obtained at $1.3 \mathrm{M} \mathrm{H}_{2} \mathrm{SO}_{4}$ concentration. The high concentration of sulfuric acid means abundances of hydrogen ion $\left(\mathrm{H}^{2+}\right)$ which is causing reaction equilibrium move to the left, thus more $\mathrm{Zn}^{2+}$ attaches to $\mathrm{SO}_{4}{ }^{2-}$ and forms forming $\mathrm{ZnSO}_{4}$ as shown below the reaction:

$\left[(\mathrm{RO})_{2} \mathrm{PO}_{2}\right]_{2} \mathrm{Zn}_{(\text {org })}+\mathrm{H}_{2} \mathrm{SO}_{4(\text { (aq) }} \rightarrow \mathrm{Zn}\left(\mathrm{SO}_{4}\right)_{(\text {aq })}$ $+\left[(\mathrm{RO})_{2} \mathrm{PO}_{2} \mathrm{H}\right]_{2(\mathrm{Org})}$

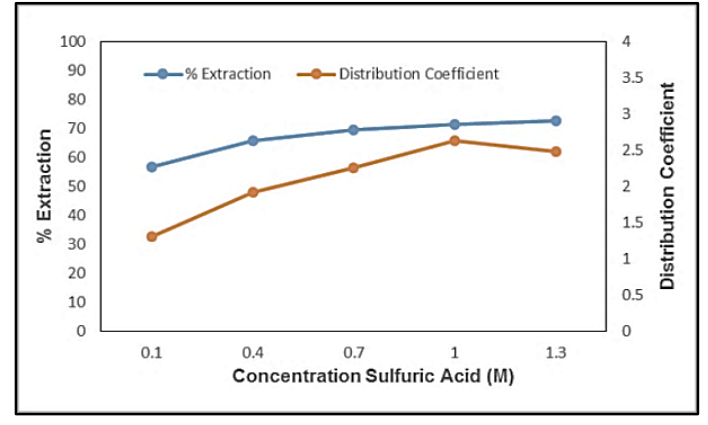

Figure 8. Influence of $\mathrm{H}_{2} \mathrm{SO}_{4}$ concentration to the percent stripping and coefficient stripping

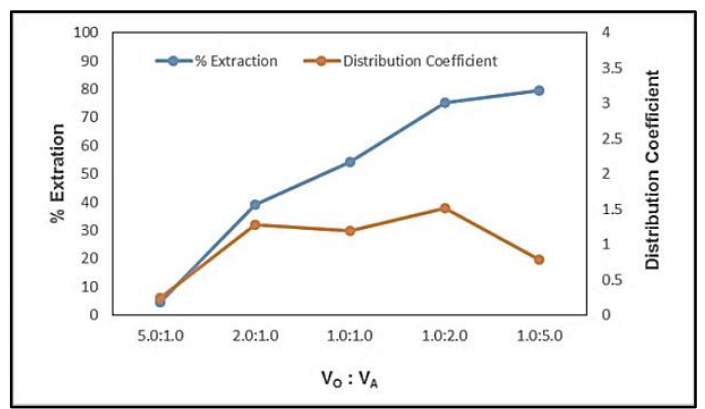

Fiture 9. Influence VO:VA to percent stripping and coefficient stripping

Usage of $\mathrm{H}_{2} \mathrm{SO}_{4}$ with a concentration of 0.4 $\mathrm{M}$ until $1.3 \mathrm{M}$ for stripping $\mathrm{Zn}^{2+}$ was also carried out by Wen-qing et al. (2003). High concentration $\mathrm{H}_{2} \mathrm{SO}_{4}$ application in their research will make the highest coefficient stripping value around 2.63 , as the highest value will cause the distribution of $\mathrm{Zn}^{2+}$ in the organic phase directly and smoothly move to the aqueous phase (Wen-qing, Zhuo-yue, Wei-zhong and Guan-zhou, 2003).

The ratio of organic solution volume to aqueous solution volume $\left(\mathrm{V}_{0}: \mathrm{V}_{\mathrm{A}}\right)$ at $1-\mathrm{M}$ $\mathrm{H}_{2} \mathrm{SO}_{4}$ concentration in Figure 9 shows that decrease value of $\mathrm{V}_{0}: \mathrm{VA}$ makes $\mathrm{Zn}^{2+}$ stripping percentage bigger. The best ratio occurred at $V_{0}: V_{A}$ 1:5 with percentage stripping $79.60 \%$. The increased aqueous volume $\left(\mathrm{H}_{2} \mathrm{SO}_{4}\right.$ solution) is being used, the more ion $\mathrm{SO}_{4}^{2-}$ attached to $\mathrm{Zn}^{2+}$ to form $\mathrm{ZnSO}_{4}$, the more increase the obtained percentage stripping (Nathsarma and Sarma, 2003).

Figure 9 also shows the highest distribution coefficient 1.51 even though the percentage stripping is $75.18 \%$. The highest distribution coefficient indicates that $\mathrm{Zn}^{2+}$ at the organic 
phase will be distributed into the aqueous phase, thus for stripping is used ratio $V_{O}: V_{A}$ in $1: 2$.

To calculate the sum of stripping stages were also used McCabe Thile diagram, such as shown in Figure 10.

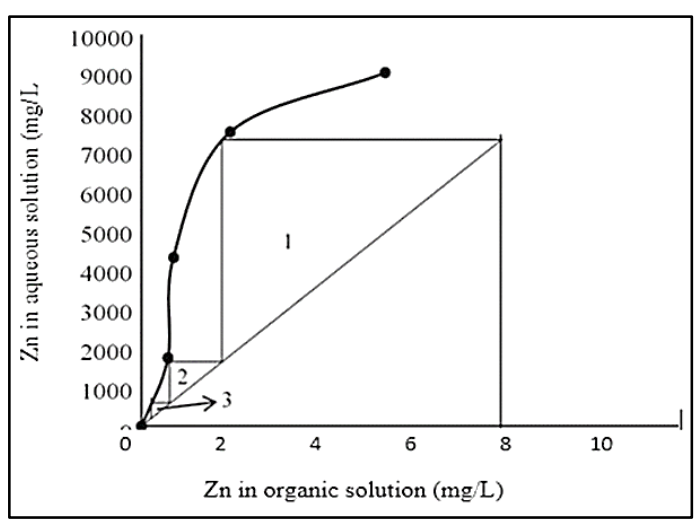

Figure 10. McCabe Thiele diagram to stripping stages

Figure 10 shows that theoretically, the $\mathrm{Zn}^{2+}$ stripping process could be carried out in 3 stages at ratio organic volume to aqueous (Vo:VA) $1: 2$ and concentration $\mathrm{H}_{2} \mathrm{SO}_{4} 1 \mathrm{M}$, resulted in stripping percentage 99.9\% (Asadi, Azizi, Lee and Jahani, 2018).

The optimum stripping condition obtained was used as raw material $\left(\mathrm{ZnSO}_{4}\right.$ pregnant solution resulted from extraction), as shown in Figure 11. This figure demonstrates that the final result of stripping carried out in 3 stages produce $98.22 \%$. The data explains that the process could not reach a percentage stripping $99.9 \%$. These are due to during extraction of other ions, such as $\mathrm{Fe}^{3+}, \mathrm{Pb}^{2+}, \mathrm{Cu}^{2+}$, which were brought into the organic phase as shown by analyses results of $\mathrm{ZnO}$ in Table 2.

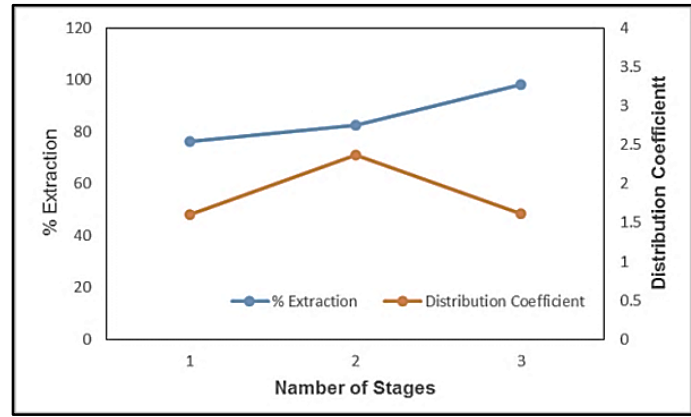

Figure 11. Percentage stripping and coefficient stripping $\mathrm{Zn}^{2+}$ done in 3 process stages.

\section{Zinc Oxide Production}

Zinc oxide production from the pregnant solution of the recovery with its results is shown in Table 2 and Figure 12. Table 2 demonstrates that $\mathrm{ZnO}$ obtained with whitecolored and purity around $93.31 \%$ and mixed with other metal oxide impurities in very small contents. Thus it is not shown in $\mathrm{XRD}$ analyses as shown in Figure 12.

$\mathrm{ZnO}$ with its purity amount $93.31 \%$ already fulfills the requirements (Habashi, 1997; Gonzalez-Valls and Lira-Cantu, 2009), even though it still contains other impurities of oxide metals such as $\mathrm{Fe}_{2} \mathrm{O}_{3}, \mathrm{CuO}$ and $\mathrm{PbO}$ as shown in Table 2.

Figure 12 demonstrates that the zinc oxide formed as zincite was confirmed by American Crystal Structure Database (AMCSD) revision number 17273, the obtained $\mathrm{ZnO}$ is hexagonal (wurtzite). This result is confirmed with the result by Wang et al. (2002) that stated that the wurtzite crystal structure was formed in $\mathrm{ZnSO}_{4}$ solution with calcination temperature of $500^{\circ} \mathrm{C}$ (Wang, Ma, Sun and Li, 2002).

Table 2. Chemical composition zinc oxide

\begin{tabular}{ccccccc}
\hline compound & $\mathrm{ZnO}$ & $\mathrm{Fe}_{2} \mathrm{O}_{3}$ & $\mathrm{CuO}$ & $\mathrm{PbO}$ & $\mathrm{Al}_{2} \mathrm{O}_{3}$ & $\mathrm{SiO}_{2}$ \\
\hline Content (\%) & 93.31 & 2.15 & 0.15 & 0.08 & 0.014 & 0.035 \\
\hline
\end{tabular}




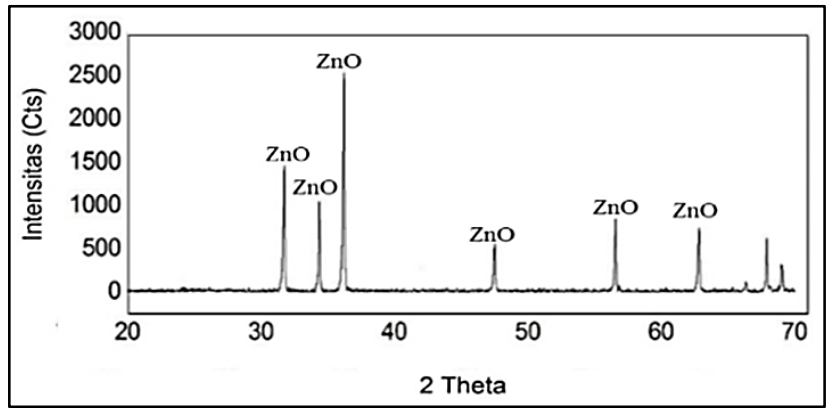

Figure 12. Zinc oxide XRD product

\section{CONCLUSIONS}

Based on the above discussion, it could be concluded that:

1. Recovery of zinc sulfate pregnant solution is as follows:

a. Percentage extraction of $97.50 \%$ with the coefficient distribution of 77.9 was obtained at the condition of D2EHPA ligand of $1 \mathrm{M}$, ratio $\mathrm{V}_{\mathrm{A}}: \mathrm{Vo}$ of $2: 1 ; \mathrm{pH}$ at 3 , with $2 \%$ excess organic volume at 4 process stages.

b. Percentage stripping $98.22 \%$ with a distribution coefficient of 1.51 was obtained at $1 \mathrm{M}$ sulfate acid concentration stripping condition, ratio $V_{0}: V_{A} 1: 2$ and 3 stripping stages.

2. Zinc oxide obtained has a purity of $93.31 \%$ with a crystal structure of wurtzite or hexagonal.

\section{ACHKNOWLEDGEMENTS}

The authors would like to thank the Head of Centre for Research and Development of Mineral and Coal Technology (tekMIRA) and Head of Geological Survey Centre, Geological Agency who provided us the opportunity to finish up the research and this manuscript. Thanks also to PT. Lumbung Mineral Sentosa for providing us the sphalerite concentrates as raw material for preliminary research, and Editor-in-Chief and Members of Editorial Boards of Indonesian Mining Journal for the publication.

\section{REFERENCES}

Arief, M. (2011) Sintesis dan karakterisasi nanopartikel seng oksida ( $\mathrm{ZnO}$ ) dengan metode pengendapan kimia basah dan hidrotermal untuk aplikasi fotokatalis. Universitas Indonesia.

Asadi, T., Azizi, A., Lee, J. and Jahani, M. (2018) 'Solvent extraction of zinc from sulphate leaching solution of a sulphide-oxide sample using D2EHPA and Cyanex 272', Journal of Dispersion Science and Technology, 39(9), pp. 1328-1334. doi: 10.1080/01932691.2017.1402338.

Balesini, A. A., Razavizadeh, H. and Zakeri, A. (2011) 'Solvent extraction of zinc from acidic solution obtained from cold purification filter cake of angouran mine concentrate using D2EHPA', Iranian Journal of Chemical Engineering, 8(3), pp. 43-47.

Gonzalez-Valls, I. and Lira-Cantu, M. (2009) 'Vertically-aligned nanostructures of $\mathrm{ZnO}$ for excitonic solar cells: A review', Energy Environ. Sci., 2(1), pp. 19-34. doi: 10.1039/B811536B.

Gupta, C. K. (2003) Chemical metallurgy: Principles and practice. Wiley-VCH Verlag $\mathrm{GmbH} \&$ Co. KGaA, Weinheim.

Habashi, F. (1997) Handbook of extractive metallurgy: Primary metals; secondary metals; light metals, Volume 2. Wiley$\mathrm{VCH}$.

Kertes, A. S. (1971) 'The chemistry of solvent extraction', in Recent Advances in Liquid-Liquid Extraction. Elsevier, pp. 15-92. doi: 10.1016/B978-0-08-0156828.50006-7.

Kislik, V. S. (2011) Solvent extraction: Classical and novel approaches. 1st Ed. Elsivier.

Kołodziejczak-Radzimska, A. and Jesionowski, T. (2014) 'Zinc Oxide-From Synthesis to Application: A Review', Materials, 7(4), pp. 2833-2881. doi: $10.3390 / \mathrm{ma} 7042833$ 
Moezzi, A., McDonagh, A. M. and Cortie, M. B. (2012) 'Zinc oxide particles: Synthesis, properties and applications', Chemical Engineering Journal, 185-186, pp. 1-22. doi: 10.1016/j.cej.2012.01.076.

Morkoç, H. and Özgür, Ü. (2009) Zinc oxide: Fundamentals, materials and device technology. 1st Ed. Wiley-VCH.

Nathsarma, K. C. and Sarma, P. V. R. B. (2003) 'Solvent extraction of cobalt and zinc sulphate solutions using phosphoric, phosponic and phophinic acid', The European Journal of Mineral Processing and Environmental Protection, 3(2), pp. 151-159.

Nyberg, J. (2004) Characterisation and control of the zinc roasting process. University of Oulu.

Sadraei, R. (2016) 'A simple method for preparation of nano-sized ' $\mathrm{ZnO}$ ', Research \& Reviews: Journal of Chemistry, 5(2), pp. 45-49.

Sigma-Aldrich (2018) 'Price List of reagents and chemicals analytical and laboratory equipment items'. Sigma-Aldrich.
Singh, R. K. and Dhadke, P. M. (2002) 'Extraction and separation studies of zinc(II) and copper(II) with D2EHPA and PC-88A from perchlorate media', Journal of the Serbian Chemical Society, 67(1), pp. 41-51.

The Directorate General of Mineral and Coal (2015) Indonesia mineral and coal information. Jakarta: The Directorate General of Mineral and Coal.

Waddar, V. N. and Behera, J. K. (2010) Study of kinetics involved in oxidation of nonferrous metal sulphide. National Institute of Technology Rourkela.

Wang, Y., Ma, C., Sun, X. and Li, H. (2002) 'Preparation of nanocrystalline metal oxide powders with the surfactantmediated method', Inorganic Chemistry Communications, 5(10), pp. 751-755. doi: 10.1016/S1387-7003(02)00546-4.

Wen-qing, Q., Zhuo-yue, L., Wei-zhong, L. and Guan-zhou, Q. (2003) 'Selective extraction of zinc from sulfate leach solution of zinc ore', Transactions of Nonferrous Metals Society of China, 13(6), pp. 1435-1439. 